\title{
EFFECT OF YELLOW FILTERS ON THE VISION
}

\author{
S. Slica, G. Ikaunieks, D. Rinkus \\ Department of Optometry and Vision Science, University of Latvia, \\ 19 Rainis Blvd., LV-1586, Riga, LATVIA
}

\begin{abstract}
In the literature, controversial information could be found whether the yellow filters may improve the quality of vision. To find out what is the effect of yellow filters on the quality of vision, 27 individuals were examined for the contrast sensitivity using the Pelli-Robson chart, under normal (photopic) and reduced (mesopic) illumination. The measurements were carried out with and without yellow filters (light transmission 67\%, measured with an Ocean Optic spectrometer). Also, the measurements were taken using a grey filter with transmission close to that of the yellow filter $(73 \%)$. The results did not show statistically significant improvement when looking through yellow filters. However, $56 \%$ of the individuals asserted that under reduced illumination they found it more agreeable to look through yellow filters. Two persons were extra tested for low contrast visual acuity using a computerized test and objective measurements by the visual evoked potentials (VEP) method. These visual measurements also did not show statistically significant improvement of the visual contrast sensitivity when yellow filters were used.

Our measurements do not confirm the data found in literature about the vision improvement owing to yellow filters. However, the mentioned above subjective improvement at using yellow filters in mesopic conditions shows that under very low illumination such filters may slightly increase the visual quality.
\end{abstract}

Key words: yellow filters, contrast sensitivity, visual acuity, VEP.

\section{INTRODUCTION}

Over the years many experiments have been carried out about the effect of the yellow filters on the visual perception [1-8]. However, there is no clear answer to the question: can the yellow filters improve vision? In various investigations different results have been obtained. Furthermore, if it is really possible, there is no clear mechanism how it is achieved.

As known, yellow filters decrease the quantity of blue light coming into the eye. Such filters would supposedly decrease the chromatic aberration of the eye and the intraocular stray light. If the image quality is optically improved, the increase both in the visual acuity and in the contrast sensitivity should be expected; however, the improvement of the contrast sensitivity is not unequivocal [3-6] and the visual acuity, looking through yellow filters, does not increase $[3,7,8]$. The improvement of the image perception with yellow filters would be more connected with neural factors (for instance, apparent increase of brightness), not optical ones $[1,2]$. An important factor in the improvement of vision when using yellow filters is the luminance of the object. According to the investigations of other authors, in low contrast conditions yellow filters make the image seem lighter and thus easier perceptible $[1,2]$. However, these investigations do not provide an answer to the 
question whether under mesopic conditions the yellow filters improve also the contrast vision. Recent investigations [4] show that under low illumination the contrast vision of the individuals after refractive surgery, looking through yellow filters, has a slight improvement; however, such an improvement was not confirmed for the control group.

Our purpose was to determine whether it is possible to obtain the changes in the contrast sensitivity function and visual acuity using yellow filters (for young people) and how these changes are affected by illumination. Also, we wanted to verify the improvement of the vision with the help of such filters, by using an objective method - that of visual evoked potentials (VEP).

\section{METHOD}

27 subjects (aged from 21 to 29) with the visual acuity 1.0 or better, without ocular pathologies or systemic diseases that could influence the results, took part in the experiment. Yellow-tinted filters from plastic material CR-39 without antireflective (AR) coating were used in the measurements. Transmission of the light was $67 \%$ (measured with an Ocean Optic spectrometer). To verify the significance of the color, also a grey-tinted filter with similar transmission of the light (73\%) was used in the experiments. In some visual measurements also a yellow filter with AR and the light transmission of $85 \%$ was used. The spectral transmittances of the filters used are shown in Fig. 1.

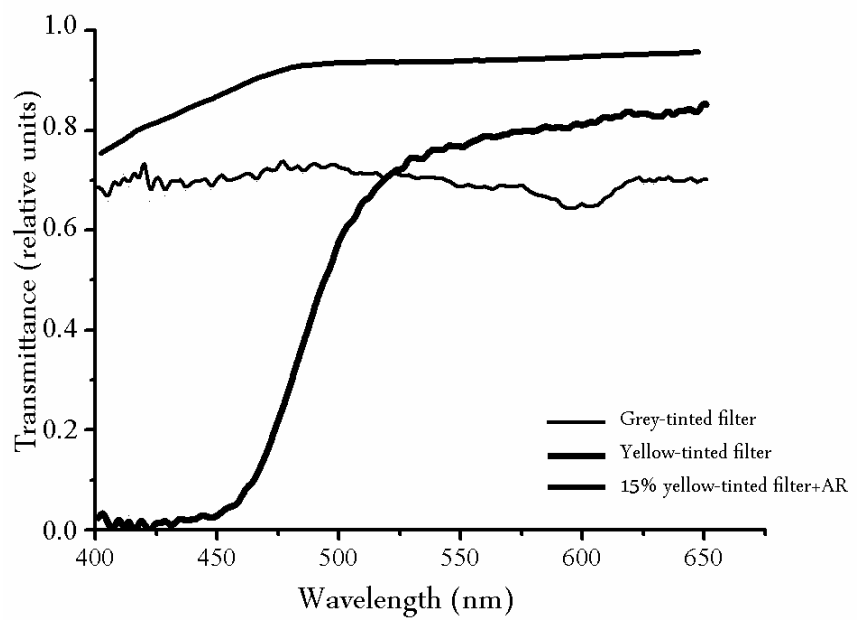

Fig. 1. Spectral transmittances of grey-tinted and yellow-tinted filters.

Three tests in total were used in the experiment: the Pelli-Robson contrast sensitivity chart [9], a computerized test for determination of the low-contrast visual acuity [10], and the VEP method - one of the methods of the visual electrophysiology [11]. The first test was applied to all subjects, whereas the second and the third ones - only to two subjects.

Pelli-Robson contrast sensitivity chart. The test consists of optotypes arranged in 8 lines. On each line of the chart there are two groups, each of three symbols. The symbols in each group have the same contrast, and the contrast of the symbols in each group is less than in the preceding group. In this contrast sensi- 
tivity chart the size of symbols is constant, but the contrast threshold decreases after each three symbols (triplet) from the top row towards the bottom one, and from the left side of the chart towards the right one (see Fig. 2). It is necessary to recognize 2 or 3 letters from one triplet. Measurements with this test were carried out under photopic (background luminance $60 \mathrm{~cd} / \mathrm{m}^{2}$ ) and mesopic conditions $\left(0.35 \mathrm{~cd} / \mathrm{m}^{2}\right)$. The test was demonstrated binocularly at a distance of $1.5 \mathrm{~m}$, each optotype size being $1.5 \mathrm{c} / \mathrm{deg}$. The subjects performed three measurements (without lens, with a yellow filter and with a grey filter) at each illumination level. As was said above, the method was applied to all 27 subjects.

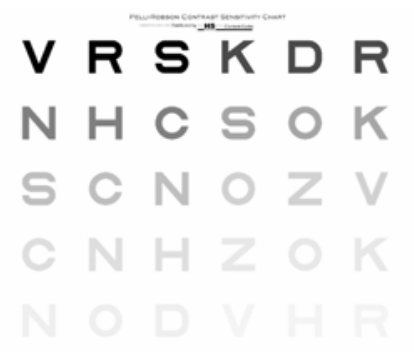

Fig. 2. The Pelli-Robson contrast sensitivity chart [9].

Low-contrast visual acuity test. Another test used in the experiment was the Freiburg Visual Acuity and Contrast Test (FrACT) [10]. Black Landolt C optotypes were taken as stimuli, and they were shown using the adaptive staircase procedure. The stimuli were demonstrated on a CRT monitor. The luminance for all backgrounds was $0.26 \mathrm{~cd} / \mathrm{m}^{2}$ (Minolta CS-100). The distance from the monitor was $3.5 \mathrm{~m}$, and the stimulus contrast $-15 \%$. The low-contrast visual acuity of two subjects was determined using neutral and grey filters without AR, and yellow filters without and with AR.

Visual evoked potentials (VEP) method, adopted from the visual electrophysiology and used in clinics for evaluation of visual systems. According to this method, to the patient's head special electrodes are attached. Biosignals can be recorded from the visual system, which can be accessed analyzing the recorded biosignal response to the stimuli.

The preferred stimulus for most clinical purposes is a reversal pattern. The standard pattern is a high contrast black-and-white checkerboard, which also was used in this measurement (see Fig. 3). All checks should be square and there should be an equal number of light and dark checks changing with a frequency of $1 \mathrm{~Hz}$ by the ISCEV standard [11]. In our measurements each square size was $0.87 \mathrm{c} / \mathrm{deg}$.

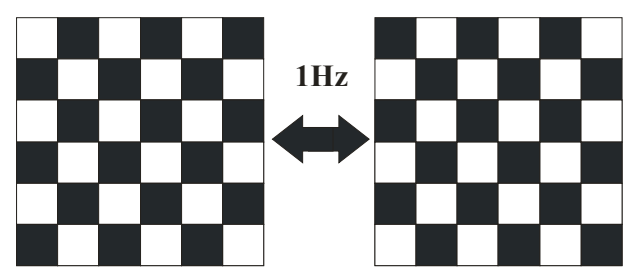

Fig. 3. Periodically changing stimuli in VEP. 
We analyzed the amplitude of recorded evoked potentials, which was measured from the first maximum peak to the next minimum peak. The amplitude became smaller if there were problems with the detection of stimuli.

The test was done monocularly at a distance of $1.5 \mathrm{~m}$ in compliance with the ISCEV recommendations [11]. The background luminance was $11 \mathrm{~cd} / \mathrm{m}^{2}$, and the test was run using a low checkerboard contrast $(15 \%)$, since it could be expected that the low contrast will give greater improvement with yellow filters [4]. The amplitudes were determined for two subjects, in addition using neutral and grey filters without AR, and yellow filters without and with AR.

\section{RESULTS AND DISCUSSION}

Evaluation of the measurements with the Pelli-Robson contrast sensitivity chart is shown in Fig. 4.

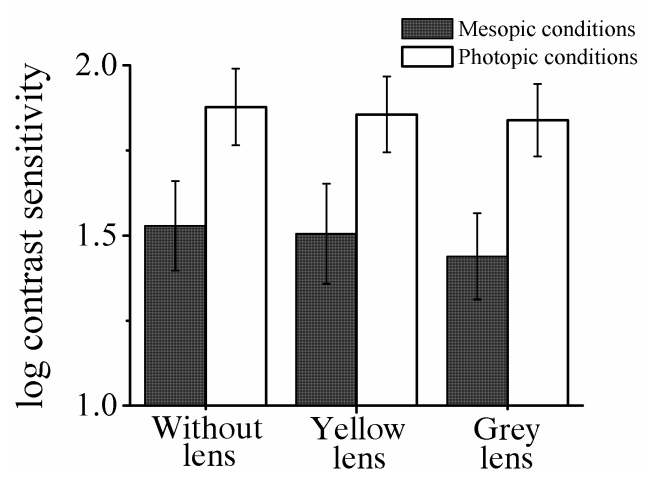

Fig. 4. Average log contrast sensitivity of 27 subjects under mesopic (background luminance

$\left.0.35 \mathrm{~cd} / \mathrm{m}^{2}\right)$ and photopic $\left(60 \mathrm{~cd} / \mathrm{m}^{2}\right)$ conditions measured without filters, with yellow and grey filters. Standard deviations for each bar are shown.

Under photopic conditions all measurements carried out without filters, with yellow and grey filters, did not show statistically significant differences for the contrast sensitivity. Under mesopic conditions, significantly lower contrast sensitivity was observed when looking through the grey filters. The results obtained in the measurements without filters and with the yellow filters were not much different under mesopic conditions.

The results show that the yellow filters do not increase or decrease either the photopic contrast sensitivity or the mesopic contrast sensitivity. As already mentioned, investigations of other authors show that yellow filters may enhance the mesopic contrast sensitivity [4]. Our data do not validate these results. One of the reasons could be dissimilar contrast sensitivity tests, with different measurement accuracy in both of them. In the Pelli-Robson test the contrast sensitivity can be measured with a step of $0.15 \log$ units (each letter size was $1.5 \mathrm{c} / \mathrm{gr}$ ); however, the enhancement of the mesopic contrast sensitivity presented by other authors for yellow filters was $0.04 \log$ units (the targets were Landolt rings of $0.3 \mathrm{c} / \mathrm{deg}$ ) [4]. In our investigation, the subjects were also questioned as to the measurements during which they had felt more comfortable in both illumination conditions. Under photopic conditions $45 \%$ subjects felt most comfortable if there were no filters 
before the eye and only $21 \%$ subjects felt more comfortable when looking through the yellow filters. However, under mesopic conditions more than half of subjects (56\%) admitted that they felt more comfortable with yellow filters than without filters before the eye. Also these results might indicate that the yellow filters may slightly increase the mesopic contrast sensitivity.

As the following ones, low-contrast visual acuity measurements for two subjects under mesopic conditions were carried out. We chose to measure the lowcontrast visual acuity because in the literature it has been mentioned that such a test may better demonstrate changes than the contrast sensitivity test [12]. These measurements were more precise than the previous ones as a computerized test was used in which the threshold was determined according to the adaptive staircase method. With this measurement run we also wanted to verify whether or not the yellow filters with greater light transmission and AR give better results than those without AR. The results of these measurements are depicted in Fig. 5.

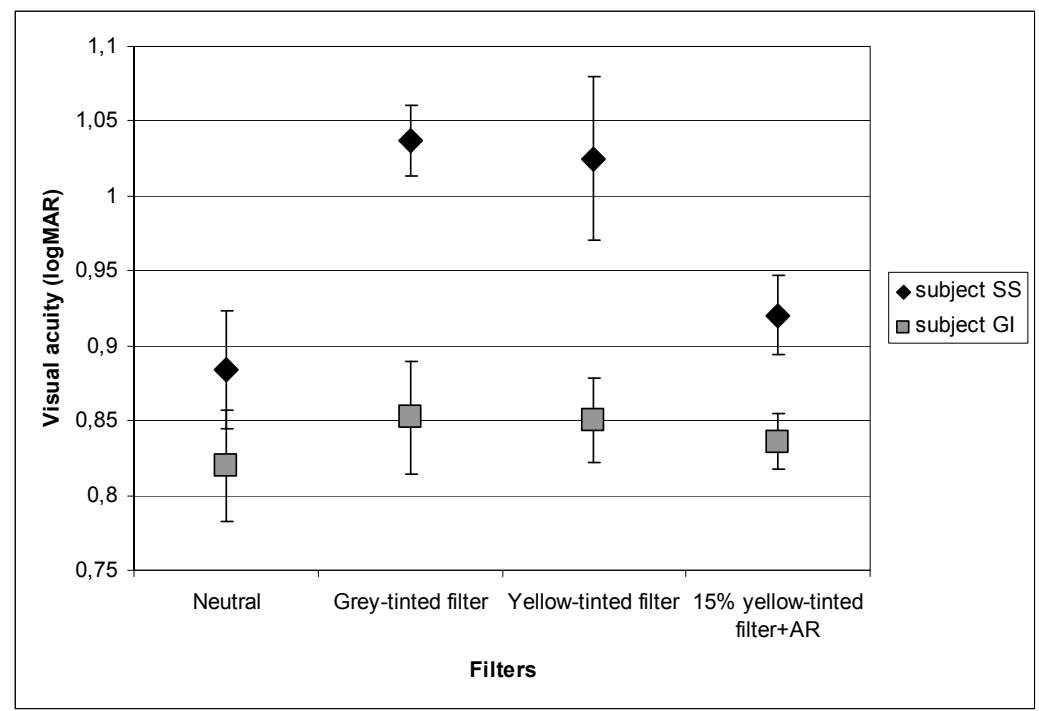

Fig. 5. Average logMAR low-contrast visual acuity of 2 subjects under mesopic conditions, measured with neutral, grey, and yellow filters, without AR and $15 \%$ yellow-tinted filters with AR. Lower $\log$ MAR values mean a better visual acuity. Standard deviations for each bar are shown.

However, despite having better measurement accuracy, none of the subjects showed significantly better results with the yellow filters.

Both the subjects were also exposed to visual electrophysiological measurements, by using the same filters as in the previous measurements. The obtained VEP amplitudes are shown in Fig. 6.

Also these results did not show significantly better results when looking through yellow filters. Our results indicate that a yellow filter does not give a significant enhancement of vision in comparison with a neutral filter, but it gives a slight enhancement in comparison with a grey filter. Presumably, the accuracy also for the last two measurement runs was not high enough to find the improvement of the results with yellow filters. However, if there is some visual enhancement, it is very slight. A yellow filter is not likely to improve the vision for car drivers under mesopic conditions. It should also be taken into consideration that a yellow filter 


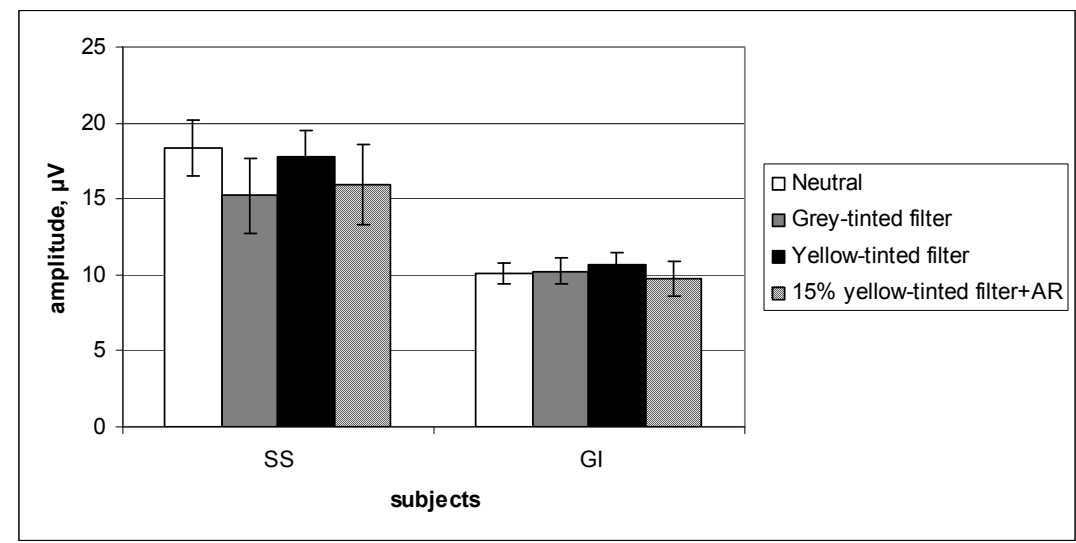

Fig. 6. Average VEP amplitude in low contrast (15\%) of 2 individuals, measured with neutral, grey, and yellow filters without AR and 15\% yellow-tinted filters with AR. Standard deviations for each bar are shown.

increases the retinal straylight [13], especially if there is a strong luminous source in the visual field (the lights of cars coming from the opposite direction). This fact even more decreases the possibility that under mesopic conditions the yellow filters could improve the vision of car drivers.

\section{CONCLUSIONS}

A yellow filter with the light transmission of $67 \%$ does not have a significant influence on the contrast sensitivity and the low-contrast visual acuity - neither under mesopic conditions, nor under photopic conditions.

Under mesopic illumination the majority of individuals found it more agreeable to look through a yellow filter than to do it without filter, so it cannot be excluded that at low illumination a yellow filter can slightly help to perceive lowcontrast objects.

\section{ACKNOWLEDGEMENT}

Gatis Ikaunieks is grateful for support by the European Social Fund.

\section{REFERENCES}

1. Kelly, S.A. (1990). Effect of yellow-tinted lenses on brightness. Optical Society of America, 7 (10), 1905-1911.

2. Rabin, J., \& Wiley, R. (1996). Differences in apparent contrast in yellow and white light. Ophthalmol. Physiol. Opt., 16 (1), 68-72.

3. de Fez, M.D., Luque, M.J., \& Viqueira, V. (2002). Enhancement of contrast sensitivity and losses of chromatic discrimination with tinted lenses. Optometry and vision science, 79 (9), 590-597.

4. Pérez-Carrasco, M. J., Puell, M.C., Sánchez-Ramos, C., López-Castro, A.,\& Langa, A. (2005). Effect of a yellow filter on contrast sensitivity and disability glare after laser in situ keratomileusis under mesopic and photopic conditions. Journal of Refractive Surgery, 21, 158-165.

5. Rodríguez-Galietero, A., Montés-Micó, A., Muñoz, G., \& Albarrán-Diego, C. (2005). Comparison of contrast sensitivity and color discrimination after clear and yellow 
intraocular lens implantation. Journal of Cataract Refractive Surgery, 31 (9), 17361740.

6. Rodríguez-Galietero, A., Montés-Micó, R., Muñoz, G., \& Albarrán-Diego, C. (2005). Blue-light filtering intraocular lens in patients with diabetes: contrast sensitivity and chromatic discrimination. Journal of Cataract Refractive Surgery, 31 (11), 2088-2092.

7. Stringham, J. M., \& Hammond, Jr., B.R. (2007). The glare hypothesis of macular pigment function. Optometry and vision science, 84 (9), 859-864.

8. Wolffsohn, J.S., Cochrane, A.L., Khoo, H., Yoshimitsu, Y., \& Wu, S. (2000). Contrast is enhanced by yellow lenses because of selective reduction of short-wavelength light. Optometry and vision science, 77 (2), 73-81.

9. Department of Psychology (New York University), Pelli-Robson Contrast Sensitivity Chart. In: http://www.psych.nyu.edu/pelli/pellirobson/.

10. Bach, M., (2007). The Freiburg Visual Acuity Test-variability unchanged by post-hoc re-analysis. Graefes Arch.Clin.Exp.Ophthalmol. 245(7), 965-971.

11. Odom, J.V., Bach, M., Brigell, M., Holder G.E., McCulloch, D.L., Tormene, A.P., \& Vaegan,? (2009 update). ISCEV standard for clinical visual evoked potentials. Doc Ophthalmol. 120 (1), 111-9.

12. Evans, D.W. (2005) FDA UPDATE: Contrast sensitivity testing standards. Ophthalmology management. In: http://www.ophmanagement.com/article.aspx?article=86281.

13. Ikaunieks, G., Ozolinsh, M., Stepanovs, A., Lejiete, V. \& Reva, N. (2009). Factors influencing light scattering in the eye. Latv. J. Phys. Tec. Sci., 46 (?), 37-42.

\section{DZELTENĀ FILTRA IETEKME UZ REDZI}

\section{S. Slica, G. Ikaunieks, D. Rinkus}

\section{Kopsavilkums}

Literatūrā atrodama pretrunīga informācija par to, vai dzeltenie filtri var uzlabot redzes kvalitāti. Lai noskaidrotu, kāda ir dzeltenā filtra ietekme uz redzes kvalitāti, 27 subjektiem tika noteikta kontrastjutība, izmantojot Pelli-Robson tabulu, normālos un pazeminātos apgaismojuma apstākḷos. Mērījumi tika veikti bez un ar dzelteno filtru (gaismas caurlaidība 67\% mērīts ar Ocean Optic spektometru). Vēl tika veikti mērījumi, izmantojot pelēku filtru ar līdzīgu caurlaidību kā dzeltenai lēcai $(73 \%)$. Rezultāti neuzrādīja statistiski nozīmīgu uzlabojumu skatoties cauri dzelteniem filtriem. Tomēr $56 \%$ subjektu ziņoja, ka pazeminātos apgaismojuma apstākḷos viņiem patīkamāk bija skatīties cauri dzelteniem filtriem. 2 subjektiem papildus tika veikti zema kontrasta redzes asuma mērījumi ar datorizētu testu un objektīvi mērījumi ar redzes elektrofiziologijas metodi (VEP). Arī šie mērījumi neuzrādīja statistiski nozīmīgu uzlabojumu, skatoties cauri dzelteniem filtriem.

Mūsu mērījumi neapstiprina literatūrā atrodamos datus par redzes contrastjutības uzlabošanos, skatoties cauri dzelteniem filtriem. Iegūtais subjektīvo sajūtu uzlabojums, skatoties cauri dzelteniem filtriem mezopiskos apstākḷ̆os, rāda, ka lıoti zema apgaismojuma apstākḷıs dzeltenais filtrs varētu dot nelielu redzes kvalitātes uzlabošanos. 